\section{DE NOVO 'A GUERRA DE TROIA'... AGORA EM LISBOA MÁRIO DE CARVALHO, A INAUDITA GUERRA DA AVENIDA GAGO COUTINHO}

\author{
Maria de Fátima Silva* \\ Recebido em: 15/04/2019 \\ Aprovado em: 06/05/2019
}

RESUMO: O conto que o escritor português Mário de Carvalho intitulou A inaudita guerra da Avenida Gago Coutinho, que centra uma coletânea de contos a que dá título, transfere para a realidade da 'guerra diária' do trânsito lisboeta um recontro que tem por motivo inspirador a épica homérica. Trata-se, portanto, da transposição para uma situação contemporânea, de 'conflituosidade prolongada', de figuras, situações e linguagem marcadas pela convenção homérica. O evidente desfasamento entre a contemporaneidade da situação e a tonalidade estética que lhe dá forma contribui para criar um tom satírico muito próprio deste autor, um bem sucedido 'cronista' da realidade portuguesa de hoje.

PALAVRAS-CHAVE: Literatura portuguesa; conto; épica; tradição clássica.

\section{'THE WAR OF TROY' AGAIN... NOW IN LISBON $M A R I O D E$ CARVALHO, A INAUDITA GUERRA DA AVENIDA GAGO COUTINHO}

\author{
* Professora \\ Catedrática, \\ Instituto de Estudos \\ Clássicos, Centro de \\ Estudos Clássicos \\ e Humanísticos, \\ Universidade de \\ Coimbra.
}

fanp13@gmail.com

\begin{abstract}
The short story A inaudita guerra da Avenida Gago Coutinho (The never heard war of Gago Coutinho Avenue), by Mário de Carvalho, gives the title to a collection of short narratives by this Portuguese author. As a subject, it transfers to the 'everyday war' of Lisbon traffic a conflict inspired by Homer's epic. This means, then, the transference to a contemporaneous situation of figures, context, and language marked by the Homeric convention. The clear disconnexion between the contemporaneous situation and the style of the text contributes to create a satyrical tonality, which identifies this very well known narrator of Portuguese actuality.
\end{abstract}

KEYWORDS: Portuguese literature; short narrative; epics; classical tradition. 
$\mathrm{N}$ o conto que centra e dá título à coletânea $A$ inaudita guerra da Avenida Gago Coutinho, ${ }^{1}$ Mário de Carvalho ${ }^{2}$ aposta, como eixo central, no anacronismo histórico manipulado em contexto de guerra. Está em causa um recontro paradigmático entre duas hostes, em plena Lisboa, num inusitado conflito em que história e ficção se confundem: de um lado o invasor árabe que, na primeira metade do séc. XII, de facto anexou ao seu poder o sul da Ibéria e, com ele, a capital portuguesa; ${ }^{3}$ do outro, os cidadãos e a autoridade urbana de uma Lisboa do séc. XX, surpreendidos por tão estranho e incompreensível recuo no tempo. De facto, ao que se narra não falta um fundo histórico, apesar do anacronismo: a realidade medieval e contemporânea portuguesas colocadas lado a lado. ${ }^{4}$

\footnotetext{
${ }^{1} 2006$ (9. ed.). Lisboa: Caminho. Como é prática conhecida de Mário de Carvalho, o título combina real e ficção. "Inaudita" é a palavra que, confrontada com um conhecido topónimo lisboeta - "Avenida Gago Coutinho" -, antecipa infiltrações de fantasia num contexto que pretende ser objetivo. Comenta a propósito Silvestre (1998, p. 213-14) que é sobretudo na narrativa curta que o fantástico e o absurdo encontram a sua forma de expressão em Mário de Carvalho.

${ }^{2}$ Nascido em Lisboa em 1944, Mário de Carvalho é um apreciado autor da Literatura Portuguesa contemporânea, com uma vasta obra publicada e premiada. São diversificados os géneros que cultiva: romance, conto, ensaio, literatura dramática. Licenciado em Direito, abandonou a atividade da advocacia para se dedicar por inteiro à produção literária. Do ponto de vista que em particular neste momento nos interessa - o da receção clássica -, Mário de Carvalho tem regressado aos clássicos greco-latinos, antes de mais sob forma de 'romances históricos' (Um deus passeando pela brisa da tarde; 400 mil sestércios), marcados pela presença romana na cultura portuguesa. Mas particularmente sugestiva é a inserção que faz de temas e motivos clássicos numa narrativa focada no contemporâneo português, valorizando o 'anacronismo' como uma poderosa fonte de insólito e de ironia.

${ }^{3}$ Os séc. VIII-XIII são na Península Ibérica tempos de conflito e confronto entre os diversos reinos cristãos e as incursões de muçulmanos, que se manteriam na região até ao séc. XV. Este inimigo oriental de há séculos (desde o séc. VII) que se movia a partir da Arábia, sob a insígnia de uma guerra santa, mas com certeza também com um projeto de amplo alargamento do seu território e influência. Depois que Portugal foi reconhecido como reino autónomo em 1143, além de definirem fronteiras em relação a Leão e Castela, os primeiros monarcas preocuparam-se igualmente com o chamado movimento de 'reconquista', voltado contra os muçulmanos do sul, ao mesmo tempo que promoviam o alargamento do território. Depois da tomada de Santarém, D. Afonso Henriques conquistou Lisboa (1147) e, de seguida, estendeu o seu domínio a Sintra, Almada e Palmela, de modo a poder assegurar a sua autoridade sobre a região. Lisboa era então uma das cidades poderosas do império árabe na Península Ibérica. Além de a sua posição geográfica fazer dela um entreposto comercial importante e um ponto de contacto entre a Europa e a África privilegiado, tinha também um enorme potencial agrícola. Em 1148, data da invasão berbere imaginada por Mário de Carvalho, estaria em causa o recrudescer do conflito histórico vivido no ano anterior (cf. $A$ inaudita guerra, p. 28: "É que, nessa ocasião mesma, a tropa do almóada Ibn-el-Muftar, composta de berberes, azenegues e árabes em número para cima de dez mil, vinha sorrateira pelo valado, quase à beira do esteiro de rio que ali então desembocava, com o propósito de pôr cerco às muralhas de Lixbuna, um ano atrás assediada e tomada por hordas de nazarenos odiosos").

${ }^{4}$ O próprio Mário de Carvalho, em depoimento feito a alunos de uma escola secundária de Gaia (cf. Pereira; Flores, 1999, p. 93), comentava a propósito desta fusão de momentos distantes da história
} 
E assim o cenário é o de um engarrafamento de trânsito muito caraterizador da realidade imediata, inusitadamente atropelado pela marcha guerreira do invasor berbere.

Porque se trata de um conflito 'armado' - guerreiros árabes de um lado, Polícia de Segurança Pública do outro -, a tradição épica da descrição da guerra parece apropriada como modelo narrativo. Homero, na qualidade de autor da Ilíada e narrador da célebre guerra às portas de Troia, é então eleito como modelo natural, consignados, no velho poema que fundamenta a literatura europeia e a do ocidente, elementos que passaram a fazer parte de uma forte convenção no que toca à narrativa do combate.

Mas se a estrutura, os intervenientes, os recursos literários, são claramente inspirados em Homero, o tom irónico que se sobrepõe ao conjunto convida o autor a subverter, com habilidade, recursos e efeitos. ${ }^{5}$ Numa palavra, sem abdicar dos processos épicos, Mário de Carvalho propõe-nos uma anti-epopeia, valendo-se sobretudo de uma chave decisiva para obter este resultado: o anacronismo. ${ }^{6}$

\section{A estrutura épica subJaCENTE À AÇÃo}

Se familiarizados com a estrutura que a épica estabeleceu e transmitiu como sua, ao longo dos séculos, não deixaremos de reconhecer no conto de Mário de Carvalho, apesar da brevidade - uma das divergências imediatas que se patenteia no texto português em relação à extensão tradicional da epopeia -, o regresso às suas componentes habituais.

portuguesa: "O que me levou a escrever a Inandita ... e por que razão misturei épocas distintas: foi a consciência de que Portugal é um país muito antigo, muito miscigenado, percorrido por muitas culturas e civilizações, de modo que cada um de nós é mais do que ele próprio, porque tem atrás de si uma grande espessura de História".

${ }^{5}$ Vieira (2009, p. 6), ao definir a perspetiva do seu estudo dedicado a esta coletânea de Mário de Carvalho, comenta: "Veremos que a peculiaridade da literatura pós-moderna se pauta pelo afastamento das concepções românticas de História, uma vez que já não interessa utilizar os grandes nomes ou os grandes acontecimentos dos tempos idos com intenções moralizantes, didácticas e pedagógicas, mas sim, para os parodiar, com o intuito de desmitificar a importância conferida a certos nomes e episódios".

${ }^{6}$ Reis e Lopes (2007, p. 130) assinalam o início in medias res e a analepse como estratégias comuns na epopeia para fraturar o curso linear da história narrada. Ou seja, ao usar o anacronismo, ainda que de uma forma talvez mais gritante face à divergência temporal dos próprios contendores que põe em confronto, mesmo assim Mário de Carvalho não deixa de estar em sintonia com uma tradição épica. Outros critérios literários presidem também à conceção deste conto, desde logo a antinomia verosímil / inverosímil. E se, como afirma Aguiar e Silva (1982, p. 483), "O princípio da verosimilhança exclui da literatura tudo o que seja insólito, anormal, estritamente local ou capricho da imaginação”, a combinação deste princípio com o seu contrário - o insólito, o anormal, o fantástico -, só pode produzir um efeito profundamente irónico e risivel no seu resultado. Mário de Carvalho parte do inverosímil - a troca de datas e a confluência de situações anacrónicas - e procura dar-lhe um tom de verosimilhança, com o recurso a espaços, personagens e gestos que soam ao leitor contemporâneo como conformes à sua realidade empírica. 
Para começar, algo semelhante a uma invocação à musa e a uma proposição, a anteceder a narração propriamente dita, não faltam em $A$ inaudita guerra. E para que, ao leitor, a fonte clássica apareça como uma evidência, as primeiras palavras são a menção do velho poeta do passado (p. 27): "O grande Homero às vezes dormitava, garante Horácio". $7 \mathrm{O}$ estudioso não deixa de vislumbrar, sob esta referência ao sono de Homero, uma vaga alusão a tudo aquilo que, na Ilíada e na Odisseia, são quebras ou inconformidades arqueológicas, linguísticas, narrativas, constituindo matéria para a famigerada 'questão homérica'. Dormir, quando se trata de um poeta - explica o narrador -, acontece "com prejuízo da toada e da eloquência do discurso"; e assim resume as múltiplas questões identificadas no texto homérico, de grande fôlego para a avaliação do poema, a quebras de ritmo e de estilo. ${ }^{8}$

Às desatenções dos poetas, sucedem-se as dos deuses - “... não são apenas os poetas que se deixam dormitar. Os deuses também”, p. 27 -, de modo a que a intervenção divina, soberana no traçado dos acontecimentos épicos, não perca o seu lugar de relevo. Por enquanto, é Clio, "a musa da História", aquela que está na mente do autor invocar;" não, como exemplificam a Ilíada (1. 1; 1. 484-492) e a Odisseia (1.1-2), para contribuir com a sua capacidade de memória e de clarividência auxiliando o cantor na ultrapassagem dos seus limites humanos. Bem pelo contrário: a musa continua inspiradora, é certo, mas é pela distração e pelo sono que dá a Mário de Carvalho motivo para a sua narrativa. Porque foi

\footnotetext{
7 Arte Poética 359: quandoque bonus dormitat Homerus.

${ }^{8}$ De toda a forma, a eficácia na utilização de convenções, neste caso a épica homérica, e o seu efeito parodístico dependem, naturalmente, da capacidade do leitor de reconhecer o ponto de partida, para poder extrair da deformação literária todo o seu potencial. Acentua Vieira (2009, p. 15): “todos os procedimentos de construção textual e técnicas que os autores tendem a esconder no texto, nas obras metaficcionais são postas em evidência, revelando como o texto é um artefacto construído mediante uma série de convenções compartilhadas pelos seus leitores/intérpretes”.

${ }^{9}$ Como sempre, trata-se, em Mário de Carvalho, de solicitar de uma entidade sobrehumana apoio para uma empresa transcendente que ultrapassa a capacidade humana do poeta ou narrador. A invocação à musa, uma componente externa da estrutura épica, é feita com frequência por Mário de Carvalho, introduzindo em contexto de narrativa - conto ou romance - um recurso sobretudo conhecido como próprio do poema épico; cf., e. g., 2004 (3. ed.), Fantasia para dois coronéis e uma piscina. Lisboa, Caminho, p. 17: "Parte, pois, vai pensamento sobre asas douradas, foge, deixa-te levar pela gentil Polímnia, grácil musa que por mim zela, e que não rejeito invocar, busca-me o lugar geográfico daquelas falas ...". Com uma figura poética que traz de imediato 'as palavras aladas' de Homero à lembrança do leitor, promove-se, neste caso, o apelo a Polímnia, a Musa "de muitos hinos", patrocinadora de muitas tonalidades ou géneros, conciliadora entre a velha épica e o romance contemporâneo, em total indiferença pelo lapso temporal e pela discrepância poética. Desta vez, o patrocínio que se espera da musa é sobretudo estético: 'pensamento' e 'musa' fundem-se, sem esquecer a cooperação da mesma deusa como memória, funcionando como arquivo de informação para dados tão vulgares como o lugar geográfico onde se situa o episódio; cf. ainda Fantasia, p. 20; p. 227, onde novas invocações à musa assinalam passos decisivos na narrativa.
} 
ela que, ao confecionar o tecido da História, ${ }^{10}$ confundiu os fios, e com uma simples troca de data - 1148 por 1984 - esteve na origem do anacronismo central na narrativa.

Ao conto não falta também a proposição, ou seja, a síntese dos dados essenciais ao desencadear da narrativa (p. 27-28). Os tópicos são os tradicionais: a menção e caraterização genérica dos beligerantes, o local da ação e os ruídos da guerra - um elemento forte na convenção do combate. Tal como no paradigma 'guerra de Troia' - uma campanha entre Troianos e Aqueus -, os dois campos em confronto, em plena Lisboa, primam pelo contraste civilizacional: são eles, de um lado, os automobilistas engarrafados que enfrentam, do outro lado, a invasão bárbara dos árabes. O local do recontro é a Avenida Gago Coutinho, uma bem conhecida artéria da capital portuguesa, ${ }^{11}$ que já se enche do alarido da batalha. ${ }^{12}$ Mas se o traçado do combate é o tradicional, o anacronismo que lhe está associado é uma marca que vai constituir a espinha dorsal da narrativa. De um lado avultam (p. 27-28) "um estridente rumor de motores desmultiplicados, travões aplicados a fundo, e uma sarabanda de buzinas ensurdecedora"; do outro o "retinir de metais, relinchos de cavalos e imprecações guturais em alta grita”. Nas diferentes tonalidades, os ruídos são a identificação preambular de duas épocas e de duas civilizações: aqueles com que a tecnologia do séc. XX nos familiarizou, os do tráfego das grandes cidades, e os provocados por vozes humanas e animais, referentes a um mundo medieval ainda liberto da máquina. A disposição deste proémio aparece, no

${ }^{10}$ É interessante transcrever a descrição da «imensa tapeçaria milenária» com que Clio tece a História ( $A$ inaudita guerra, p. 27): “... repleta de cores cinzentas e coberta de desenhos redundantes e monótonos". Em poucas palavras sintetizam-se as obscuridades que o tempo lança sobre os acontecimentos, bem como as curvas repetitivas do fluxo histórico, tal como já os antigos, desde logo Heródoto, o pai da História, o concebiam. Esta ideia da tradução de episódios da História ou do mito nas linhas de um bordado é com certeza inspirada na Helena homérica (Ilíada 3. 125-128) que, nos seus aposentos, bordava em precioso tecido de púrpura o confronto entre Aqueus e Troianos de que ela mesma fora a causadora.

${ }^{11}$ Ainda que se refira a uma avenida concreta no plano urbanístico de Lisboa, a opção pela Gago Coutinho não deixa de ter o seu significado no contexto. O conhecido aviador (séc. XIX/XX) - o primeiro a fazer, em 1922, a travessia do Atlântico Sul juntamente com Sacadura Cabral -, que colocou Portugal na rota de um progresso pioneiro, será sempre paradigma da capacidade do país de se abrir ao mundo e de se afirmar pela sua história. Sugere assim um Portugal feito 'potência', apetecível a um invasor, do mesmo modo que Troia, ao tempo da épica a grande cidade do oriente. A mesma estratégia é adotada por Mário de Carvalho na menção do nome de outras artérias, como a Alameda D. Afonso Henriques (31). Também neste caso, além da designação corresponder a ruas e avenidas existentes em boa parte das cidades do país, ela é evocativa do primeiro rei português (1109-1185) e, por isso, da fundação da própria nacionalidade de Portugal (1143). O apelido de "Conquistador" que lhe foi atribuído pela História, que envolve de resto lutas contra os muçulmanos ocupantes do sul peninsular, serve bem ao contexto.

${ }^{12}$ Textos como a Ilíada ou, na mesma tradição, a tragédia Sete contra Tebas de Ésquilo, são sem dúvida modelos paradigmáticos da descrição do combate, apelativa aos ruídos e brilhos que se cruzam no campo de batalha. 
conjunto, como um habilidoso quiasmo: dos lisboetas e dos ruídos técnicos que provocam, passamos ao alarido e vozes que advêm dos árabes.

\section{ELEMENTOS NARRATIVOS DA CONVENÇÃo ÉPICA}

A narrativa que se segue - centrada na guerra - vai pôr em movimento a ação já referida e os seus agentes. Em primeiro lugar, um vislumbre de 'catálogo', o célebre motivo épico da listagem dos combatentes e meios bélicos de cada uma das partes que antecede a descrição das hostilidades, ${ }^{13}$ não deixa de estar sugerido no aprofundamento do retrato de cada uma das hostes confrontadas em Lisboa. Mas digamos que o efeito, na Ilíada 2. 493877, por exemplo, expresso no célebre e encorpado 'catálogo das naus', se reduz no conto a uma breve amostragem, em que as grandes alusões à massa dos combatentes se entremeiam com a identificação pontual dos seus chefes.

A insistência nos ruídos e nos brilhos que cruzam um campo de batalha retoma o processo já antes ensaiado na proposição (p. 28): "Viu-se de repente o exército envolvido por milhares de carros de metal, de cores faiscantes, no meio de um fragor estrondoso...". ${ }^{14}$ Os habituais batalhões, de infantes, archeiros, cavaleiros, com as suas armas emblemáticas, são, neste caso, substituídos, de um lado, por uma referência lacónica ao 'batalhão dos automobilistas', não menos sugestivos na descrição do espetáculo visual que proporcionam; e do outro, pela menção "aos cavalos", que aparecem como emblemáticos das forças de elite árabes. ${ }^{15}$

Do coletivo das forças, o foco estreita-se, como é de regra no catálogo, para a figura do chefe, identificado pelo nome e título, mas também por atributos como a família, a pátria, algum feito ou virtude que o valorize, as armas ou insígnias que enverga, compatíveis com os batalhões sob seu comando. Particularmente importante, na tática narrativa da descrição de povos e de guerreiros, é, como é bem sabido, o epíteto, o qualificativo impressionista e

\footnotetext{
13 Sobre a tradição épica do catálogo e exemplos conservados na literatura grega antiga, cf. Hall (1996, p. 108-109).

${ }^{14}$ Cf., ex., uma descrição paradigmática do combate em Ilíada 4. 446-449 de que Mário de Carvalho retoma o tom geral: "Quando chegaram ao mesmo sítio para se enfrentarem uns com os outros, brandiram todos juntos os escudos, as lanças e a fúria de homens de brônzeas couraças; e os escudos cravados de adornos embateram uns contra os outros e surgiu um estrépito tremendo" (tradução de Lourenço, 2005).

${ }^{15}$ Como emblema do coletivo, Muftar, o chefe do batalhão de cavalaria árabe, impunha uma imagem poderosa "do alto do seu puro-sangue" (p. 29). A associação dos grandes chefes homéricos com as suas montadas faz parte do retrato de Aquiles e de Heitor, os dois guerreiros de referência na Ilíada, para Gregos o primeiro e Troianos o segundo. De acordo com a tradição, Aquiles conduzia uma invejável parelha de cavalos, oferta a seu pai do próprio deus Posídon (Ilíada 16. 149-151). Conformes à imagem da planície troiana e dos cavalos que apascenta são os epítetos que valorizam a perícia equestre das tropas comandadas por Heitor, "domadoras de cavalos" (ex., Ilíada 3. 127, 3. 131, 4. 333 , 4. 352, 4. 355, 4. 509, 7. 38, 7. 361, 8. 516, 8. 525, 16. 717, 17. 230, 17. 418), ou "chicoteadoras de cavalos" (5. 102). O próprio Heitor se evidencia como auriga exímio (8. 88-90).
} 
identificador em que os poemas homéricos abundam. Usados em profusão, esses epítetos, além do seu efeito caraterizador, tornam o discurso florido e rebuscado. Todo este património literário é também percetível no texto português. "Ali-ben-Yussuf, lugar-tenente de Muftar, homem piedoso e temente a Deus" (p. 28) é o primeiro chefe a merecer atenção: desenham o seu retrato o nome, o posto que ocupa, e uma primeira qualidade (arete) de enorme relevo entre os valores ancestrais, a piedade (eusebeia). Diante do perigo, mais do que confiar nas próprias forças ou nas dos seus homens, Ali-ben-Yussuf dirige uma prece ao seu deus, um Alá protetor e grande. ${ }^{16}$ Após esta primeira suspensão, a urgência impõe aos chefes ação. Nesta perspetiva a hierarquia, que desta vez ordena as intervenções humanas na aventura militar, traz a primeiro plano o próprio Muftar, seu superior hierárquico e uma segunda figura no catálogo em formação; em vez da piedade, outras são as virtudes, desta vez militares, que lhe assistem; os seus gestos são de comando - "levantou bem alto o pendão verde e bradou uma ordem que foi repetida", p. 28 -, e a imagem constrói-se-lhe de outras marcas, a barbicha afilada e o turbante, que aludem à pátria árabe como sua origem.

Expostos os traços e os méritos, seria legítimo esperar o desencadear vigoroso do combate. Mas não, o retrato do 'herói' que vai sendo construído conduz não ao movimento, mas a uma imobilidade inesperada, como se o quadro literário que se esboça não passasse de uma imagem estática, talvez porque a História que lhe dá suporte esteja confundida por um embaraço anacrónico. "Que ninguém se mexesse!" (p. 28), foi a ordem perentória transmitida por Muftar à cavalaria árabe, como também, por Mário de Carvalho, às personagens do conto. Frustrada a prece pela urgência da situação, frustrado foi também o ataque pela determinação do chefe.

Abriu-se assim caminho à caraterização da outra parte, por processo equivalente. E aí um primeiro 'herói' se antecipa, (p. 29) "o agente de segunda classe da PSP Manuel Reis Tobias". Trata-se agora de identificar um primeiro interveniente das forças portuguesas, representado por um nome de ressonância vulgar, acompanhado pela respetiva patente (de resto, modesta ${ }^{17}$ e pela sigla da corporação a que pertence, a Polícia de Segurança Pública. ${ }^{18}$

\footnotetext{
${ }^{16}$ A mesma noção homérica de que os deuses penetram o campo de batalha e condicionam ações e resultados humanos é partilhada por Muftar que, perante a estranheza da situação, se interroga sobre a verdadeira razão do paradoxo (p. 29): "Teriam tombado todos no inferno corânico? Teriam feito algum agravo a Alá? Seriam antes vítimas de um passe de feitiçaria cristã? Ou tratar-se-ia de uma partida de jinns encabriolados?". O uso da prece a anteceder os grandes confrontos abunda, de resto, na Ilíada; cf., ex., 3. 276-279, 3. 365.

${ }^{17}$ Cf. estratégia semelhante na identificação do "comissário Nunes" (p. 31) e do "capitão Aurélio Soares” (p. 33). Esta identificação dos 'heróis' lisboetas pela patente ganha em ironia se confrontada com os títulos habitualmente atribuídos pela épica às suas personagens, a quem assiste a nobreza de sangue e o estatuto de soberanos.

${ }^{18}$ A referência à corporação substitui, também com ironia, a menção tradicional ao reino de que os combatentes são oriundos, em geral coincidente com as grandes sedes civilizacionais do mundo antigo. Apenas um exemplo pode marcar o tom homérico e denunciar a 'demolição' paródica do texto português (Ilíada 2. 559-568): “Os que eram senhores de Argos e de Tirinto amuralhada, de
} 
A piedade e determinação na ordem que marcava o lado invasor - o bárbaro - parece, à primeira vista, ceder lugar, quando se trata da defesa, a uma cobardia bem sublinhada no resistente urbano e civilizado 19 (p. 29): "meio escondido por trás das colunas de um prédio". No entanto, o observador avisado perceberá que não se trata afinal de cobardia, mas de uma estratégia de investida sobre o cidadão - a conhecida 'caça à multa' -, que identifica a personagem com um traço profissional bem nítido (p. 29): “... no propósito sábio e louvável de surpreender contraventores aos semáforos”. É esta a arete do agente da autoridade nos nossos dias.

O recurso às hierarquias de comando, para ouvir argumentos que norteiem futuras decisões, está consignado na épica por múltiplas 'assembleias' de chefes, quer do lado grego, quer do troiano, ${ }^{20}$ que marcam pausas entre fases decisivas na estratégia de guerra e definem as atitudes a tomar pelos respetivos subordinados. A mesma estratégia, traduzida para uma lógica contemporânea, executa-se com recurso a uma transmissão à distância, por um intercomunicador com a central, de onde um superior hierárquico irá ditar a reação a assumir. A partir desta primeira consulta, outras vozes irão intervir no debate, por uma cadeia de telefonemas "para o governador civil e deste para o ministro" (p. 29). O resultado, em paralelo com o definido pelo adversário, aponta para o mesmo imobilismo, aconselha suspensão (p. 29): "De lá lhe disseram que iriam providenciar e que se limitasse a presenciar as ocorrências, mas sem intervir por enquanto". Reforça-se, com esta determinação da chefia adversária, a fixidez a completar o quadro do anacronismo histórico.

\section{O COMBATE}

Foi só então, depois de estabelecido o rosto da chefia e de consultadas, à distância de acordo com os meios contemporâneos, as hierarquias, que o coletivo local se fez presente, com os seus batalhões (p. 30): "Soaram as sirenes no quartel de Belém e poucos minutos depois, alguns pelotões da Polícia de Intervenção vinham a caminho, com grande alarde de sereias e pisca-piscas multicores". Por sua vez o inimigo respondeu com a colocação das tropas no terreno. Mas o desencadear das hostilidades ocorreu, como na Ilíada 4.85 sqq., pela intervenção de um agente estranho às vozes de comando, Manuel da Silva Lopes, o condutor de um camião carregado de grades de cerveja, no papel do Pândaro épico. A alusão é agora clara ao passo homérico em que, depois que o duelo entre Menelau e Páris pela posse de Helena terminou inconcluso e as tropas dos dois lados se quedaram em suspenso, a deusa

Hermíone e de Ásina recortadas pela baía funda; Trezena e Eionas e Epidauro cheio de vinhas, senhores de Egina e de Mases, mancebos dos Aqueus; deles era comandante Diomedes, excelente em auxílio, e Esténelo, filho amado do glorioso Capaneu. Com eles vinha um terceiro, Euríalo, homem divino! filho do soberano Mecisteu, filho de Talau. Mas a todos eles comandava Diomedes, excelente em auxílio, e com eles seguiam escuras naus em número de oitenta". Tradução de Lourenço, 2005. ${ }^{19}$ Esta é, naturalmente, a subversão das habituais caraterísticas de grego e bárbaro na tradição grega antiga, valente e civilizado o primeiro, selvagem e cobarde o segundo.

${ }^{20}$ Ex., Ilíada 1. 57-305, 2. 53-149, 211-393, 3. 146-160. 
Atena incentivou o troiano Pândaro a disparar uma seta contra Menelau, que se torna no rastilho para a generalização do combate. O bathos no protagonista do episódio não pode ser mais flagrante. Manuel da Silva Lopes, um simples cidadão desconhecido e modesto, motivado pelo impasse que o engarrafamento de trânsito impôs a todos - automobilistas e beligerantes -, também ele vítima de uma má inspiração provinda do ‘destino' - “resolveu em má hora", p. 31 -, serviu-se de um "calhau miúdo" (em vez do arco e flecha do Troiano, Ilíada 4. 112), com que alvejou um adversário, o beduíno Mamud Beshewer. Ao contrário de Menelau, ainda ansioso após um duelo violento (Ilíada 4. 115), o visado é também agora um simples infeliz que se encontra, por azar, na trajetória da pedra, ele que, "por ainda não ter acordado de tudo isto, era um dos mais quietos da tropa” (p. 31).

Estavam criadas condições, tal como no poema homérico, para uma primeira arremetida violenta, que, na Ilíada, haveria de conduzir ao combate encarniçado que separava ainda os beligerantes do desfecho da guerra. Em A inaudita guerra, "vinte archeiros enristaram os arcos, apontaram aos céus, e expediram, com zunido tenso, uma saraivada de setas" (p. 31); enquanto, do lado oposto, “o comissário Nunes, à frente dos seus pelotões de choque", por interpretar mal o sucedido, imaginou os manifestantes num confronto direto com a polícia. ${ }^{21}$ Por isso desencadeou um avanço à sua medida (p. 31): “Toca a varrer isto tudo até ao Areeiro - disse. E, puxando do apito, pôs a equipa em acção, à bastonada, a eito, por aqui e por além" (p. 31). ${ }^{22}$

Estavam criadas as condições para desencadear a tensão do combate, uma réplica anacrónica dos muitos episódios da Ilíada em que o fragor e o movimento da guerra envolvem os heróis. $\mathrm{O}$ avanço da Polícia de Intervenção não se mostrou fácil, perante o acumular de populares e de combatentes. As primeiras 'baixas' não se fizeram também esperar (p. 31), "conseguiram chegar ao Areeiro algum tempo depois, após muita cabeça partida e duas baixas nas suas hostes, de agentes que tinham sido sabiamente atraídos a vãos de escadas por populares mais expeditos”. Ferimentos ligeiros, infligidos à traição em lugares esconsos, por adversários oportunistas, mas desproporcionados na valentia, eis o que caraterizou esta primeira arremetida decisiva. Houve que corrigir a estratégia, com uma rearrumação de efetivos, reconduzidos pelo áristos do momento, o comissário Nunes, para "a placa relvada" da Praça do Areeiro. Do lado contrário, o inimigo sofria também os seus reveses: primeiro uma baldada de água, "que alguém havia deixado cair de uma das janelas e que lhe impregnara o manto e a cota de malha” (p. 32), deixou irritado o comandante Ibnel-Muftar, que avançou com determinação sobre o adversário, para o que ameaçava ser um

\footnotetext{
${ }^{21}$ Por trás da confusão, o comissário Nunes reage sob o efeito da turbulência nacional ainda sensível dez anos passados sobre a revolução de 25 de Abril de 1974 (sendo que a ocorrência narrada no conto (p. 27) é datada de "29 de Setembro de 1984”). Por isso interpreta a arruaça como mais uma manifestação de cidadãos contra a polícia, numa subversão do que era, antes da revolução, a repressão policial sobre o povo.

${ }^{22}$ Cf., ex., Ilíada 4. 422-431, 509-510, 5.48 sqq., para uma descrição sobre um movimento de avanço de tropas.

${ }^{23}$ Cf., ex., Ilíada 4. 457-544, sobre a descrição dos ferimentos resultantes de um recontro vigoroso.
} 
recontro violento (p. 32): "Num ápice, rompeu uma carga de cavaleiros berberes, aos gritos de guerra, de alfange em riste, ladeando automóveis, amolgando capots, e aproximando-se inexoravelmente dos rapazes do comissário Nunes". O recuo dos defensores da cidade, que não aguentaram a carga dos berberes, foi inevitável. Correram, não a refugiar-se nas muralhas de Troia ou no acampamento aqueu como os seus antepassados épicos, ${ }^{24}$ mas a procurar proteção no interior das paredes que os cercavam, no caso as da "Cervejaria Munique, onde se refugiavam atrás do balcão" (p. 32).

Nem mesmo faltou, na batalha lisboeta, a vinda de reforços, apesar de retardados pela barreira do trânsito. Ainda assim, "a tropa do Ralis e a da Escola Prática de Administração Militar" não deixaram de se fazer presentes, quando os homens do comissário Nunes se mostravam já incapazes de fazer frente à cavalaria árabe. Dificuldade que obrigou mesmo à metamorfose 'dos batalhões': de tropas motorizadas que eram, os subordinados do capitão Aurélio Soares converteram-se, em face das circunstâncias, em forças de infantaria, de modo a vencerem, em corrida, o obstáculo do engarrafamento.

Estava, no entanto, tão feroz combate fadado para terminar numa trégua sensatamente negociada. A isso aconselhava a desproporção das forças. ${ }^{25}$ Prudentes foram, portanto, as instruções dadas ao capitão Aurélio - "proceder a um reconhecimento, avaliar a situação e agir em conformidade, mas sempre com moderação" (p. 33) -, apontando todas no mesmo sentido de um apelo à imobilidade. Diante do inimigo, o capitão Aurélio Soares ergueu, à cautela, "um trapo branco", generosamente cedido por um dos moradores locais. Ainda que confrontado com um sinal cujo conteúdo lhe não era familiar, mesmo assim o árabe captou no ar o sentido pacificador do gesto e dispôs-se a negociar. Surpreendeu-se, naturalmente, quando à sua saudação em língua árabe, correspondeu um cumprimento na mesma língua (p. 34), porque, por feliz coincidência, “o capitão Soares, que tinha feito uma comissão na Guiné, em contacto com gente muçulmana”, não era ignorante do estranho idioma.

Foi assim que os homens puderam apaziguar conflitos, ainda antes de a musa Clio, a mesma que causara o embaraço, ter despertado para a necessidade de desensarilhar os fios da História, fazendo que tudo regressasse à normalidade.

\footnotetext{
${ }^{24}$ Cf., ex., Ilíada 6. 73-74; do mesmo modo recuam os Aqueus, 8. 78-79, 157-159, 343-345.

${ }^{25}$ A proporção do número de forças - atacantes e defensores de Troia - é um dado também importante na Ilíada. Os símiles que, no Canto II, retratam os movimentos do acampamento aqueu não deixam dúvidas sobre o número impressionante dos seus efetivos: 2. 87-93, comparados a um enxame de abelhas, ou, 2. 469-471, de moscas; 2. 207-210, semelhantes, no fragor que produzem, às ondas de um mar enfurecido; 2. 459-463, idênticos a bandos de aves, ou, 2. 467-468, à floração primaveril que inunda os campos. Do lado oposto, através dos contingentes presentes em Troia, a multiplicidade de cidades aliadas ganha dimensão. Íris, a mensageira dos deuses, deixa, em termos gerais, uma referência ao número e à diversidade de populações que constituem o enorme xadrez asiático (2. 803-804). Os sucessivos catálogos das forças troianas e aliadas produzem então o desdobramento deste amontoado anónimo e a identificação progressiva das diferentes células.
} 


\section{A ARTE Do ANACRONismo}

Disseminados pela narrativa, muitos são os processos formais e estéticos que reconhecemos como parte do contexto épico da Antiguidade. Ora como elementos de conteúdo, ora como padrões literários, o seu contributo para a vitalidade do conto é inegável, pelo choque claro que estabelecem com uma narrativa distante no género, e mais distante ainda no tempo. Não deixemos de observar, no entanto, que em $A$ inaudita guerra, há de facto três tempos: o da Antiguidade épica, que conforma o modelo geral da leitura dos acontecimentos e da sua narração; o da contemporaneidade, a Lisboa do séc. XX em que a ação decorre; e ainda, infiltrada pela invasão árabe, uma medievalidade de que a capital portuguesa é também cenário. O resultado final advém da manipulação hábil que Mário de Carvalho faz destes três planos para os que são elementos essenciais na narrativa. Não deixaremos de articular, com os planos anacrónicos em que a ação decorre, o fator 'linguagem', que parece acompanhar a mesma discronia. É sabido que, por tradição, a épica homérica prima pelo tom solene e requintado do estilo, colorido esse a que Mário de Carvalho não deixa de recorrer como uma marca indissociável do seu modelo. Mas, ao mesmo tempo, uma certa elaboração das palavras, usada para assinalar as narrativas de catálogo ou de combate, bem como sobretudo associada com o invasor berbere, pelo ascendente que lhe cabe face ao tempo que o integrou já na História, choca com algum plebeísmo próprio do nosso quotidiano, rebaixado à condição de um modesto e vulgar patamar de experiências bem familiares ao leitor.

Comecemos pelo estabelecimento de um cenário, o local onde os acontecimentos decorrem. Se o modelo longínquo para os feitos a narrar é Troia, o quadro esperado é aquele que opõe aos invasores a resistência das muralhas da cidade de Príamo, enormes paredes cortadas por portas também defensivas, ${ }^{26}$ que marcam as vias de acesso ao movimento e ao

\footnotetext{
${ }^{26}$ Em poucas palavras, West (2011, p. 38) sintetiza um retrato da Troia homérica: “As escavações, há mais de um século, estabeleceram que, no local onde os Gregos situavam Troia, havia, na Idade do Bronze tardia, uma cidade próspera, fortemente muralhada. Era a cidade mais importante de todo o noroeste da Ásia Menor, e uma das que tinham relações privilegiadas com o mundo micénico”. De acordo com a Ilíada, é sobretudo a robustez e magnificência da sua construção o que impressionava. "Imponente" é a descrição apropriada à cidadela de Troia (2. 332, 2. 803, 6. 392, 9. 136, 9. 278), que se orgulha de ser "bem construída" (4. 33, 21. 433). Troia tem, portanto, por seu logótipo essencial, as muralhas e as torres, que lhe transmitem uma imagem de poder e segurança, imagem tanto mais desafiadora quanto posta à prova na crise que a avassala. "De belas muralhas", "de altas muralhas" e "de belas torres" são, assim, dos seus epítetos mais insistentemente repetidos $(1.129,2.113$, 2. 288, 5. 716; 7. 71, 16. 700-702, 21. 516). De igual robustez partilham os seus portões, também eles "bem construídos" e "altos" (5. 466, 21. 544). Essas portas foram cenário de alguns dos momentos cruciais na queda iminente da cidade: a despedida de Heitor e Andrómaca e o recontro final entre o seu defensor e Aquiles (6. 392-393, 22. 6, 22. 360). Mas nem só a visão exterior da cidadela é impressionante, como é também majestoso o seu traçado urbanístico. "Ampla" (13. 433, 24. 256, 24. 494, 24. 774) é um qualificativo que engloba, genericamente, a vastidão e funcionalidade do traçado das suas ruas e uma urbanização cuidada de cidade grande, expressa no epíteto "de ruas bem construídas” (6. 391).
} 
contacto entre os dois campos de batalha. Em $A$ inaudita guerra, um invasor que já não é o exército aqueu mas sim uma hoste árabe medieval, não pode deixar de assustar-se diante das (p. 28) "paredes descomunais que por toda a parte se erguiam, cobertas de janelas brilhantes", numa configuração modernizada das 'muralhas' das metrópoles nossas contemporâneas. 'O susto’ é a tradução emotiva dos agentes de uma narrativa que os desnorteia por efeito de um anacronismo inusitado.

A uma primeira imagem global do espaço sucedem-se referências mais precisas ao seu desenho urbanístico, num golpear permanente da lógica temporal. Assim, por exemplo, o limite da ordem transmitida pelo comandante berbere às suas tropas da retaguarda situase próximo "da Rotunda da Encarnação” (p. 28); ou a disposição das tropas no terreno de batalha dispersa-se entre "o parque de estacionamento do Areeiro", "o terreiro da estação de serviço do lado contrário" e a "placa central relvada" (p. 30). Por outro lado, depois que o avanço entre os dois campos se consuma, a invasão e movimento de todos os envolvidos amplia-se pelos espaços em volta, o Bairro dos Actores (p. 31), o Bairro da Encarnação (p. 32), a Avenida dos Estados Unidos (p. 33).

Uma palavra é devida também ao fator 'tempo', porque se o espaço temporal que afasta os dois contendores no episódio é de séculos, o tempo narrativo, num enorme exercício de contenção, circunscreve-se ao fugaz adormecimento da musa Clio; como bem observa Couto (2003, p. 321), esse adormecimento, "metaforicamente, é traduzido pelo nó que logo se formou quando Clio adormeceu, destoando da lisura do tecido da tapeçaria milenária urdida pela musa da História”.

O choque registado no cenário é comum com aquele que opõe as figuras que nele se movem. São, antes de mais, os nomes o que assinala o fosso temporal - além de cultural - a separá-los. Nomes árabes - Ali-ben-Yussuf, Ibn-el-Muftar, Mamud Beshewer -, em todo o seu exotismo, friccionam com os mais portugueses nomes pessoais (Manuel Reis Tobias, Manuel da Silva Lopes, Aurélio Soares). Mas a atuação é também fraturante. Para estabelecer cadeias de comando, o árabe usa a voz e faz correr a ordem de batalhão em batalhão, por simples transmissão direta. A polícia portuguesa, por seu lado, em pleno séc. XX, recorre ao "intercomunicador da mota" (p. 29), que faz chegar ao comando "números e cifras", à primeira vista indecifráveis, mas que afinal se podem traduzir numa mensagem extensa. E porque o anacronismo torna difícil a descodificação de imagens, palavras e mensagens, a tradução do que a evidência patenteia sofre o desvio da incompreensão, que o tempo e a diferença cultural justificam (p. 29):

Uma multidão indeterminada de indivíduos do sexo masculino, a maior parte dos quais portadores de armas brancas e outros objectos contundentes, cortantes e perfurantes, com bandeiras e trajos de carnaval, montados em solípedes, tinham invadido a Avenida Gago Coutinho e parte do Areeiro em manifestação não autorizada. Dado 
que se lhe afigurava existir insegurança para a circulação de pessoas e bens na via pública, aguardava ordens e passava à escuta. ${ }^{27}$

Esta é a forma por que, também do lado do invadido, se instala a imobilidade. A incompreensão trava a energia e exige uma primeira pausa de decisão e recurso às hierarquias. O tom é o de um formalismo profissionalizante, aquele que carateriza as mensagens policiais perante a ilegitimidade de uma manifestação de rua não autorizada, paradoxal no seu aparato, entre o violento e o festivo.

Por seu lado, o chefe árabe não foi mais bem sucedido na sua interpretação do que o rodeava (p. 30):

Decidiu não se deixar impressionar com os trejeitos pouco amistosos que lhe vinham de dentro dos objectos metálicos com rodas que havia por toda a parte, nem com as caras que o fitavam por detrás de um estranho material transparente. Se era uma encantação, melhor era deixar que passasse - segredou para ben-Yussuf que lhe respondeu, desconfiado e muito pálido: - inch Allah!"’.

Também neste caso a consulta das hierarquias levou a uma interpretação, baseada em outros critérios, transcendentes e atribuídos à insuperável vontade dos deuses.

Incompreensão é, portanto, o resultado final destas manobras dilatórias, em que a apresentação das tropas e uma primeira localização no terreno prepara o romper efetivo das hostilidades.

Hostilidades que não estavam, no entanto, destinadas a acontecer. Porque da mesma forma que, com uma leve passagem pelo sono, Clio causou o conflito, foi também rápida a solução que encontrou para ele, simplesmente desfazendo o nó entretanto tecido. Apesar de tudo, consequências restaram para os diversos intervenientes no episódio. Os árabes desistiram da reconquista, fazendo a história ficcionada regressar à História verdadeira. Por sua parte, as forças de segurança portuguesas viram-se a braços com um processo, que as responsabilizava pela confusão de trânsito armada em hora de ponta em lugar de congestionamento habitual. Talvez apenas um episódio de rotina no quotidiano dos reguladores do tráfego numa grande cidade. Por fim à Musa responsável por todo este caos cronológico coube a pena pesada de quatrocentos anos privada de ambrosia, acompanhada de um comentário a considerar (p. 35): "o que, convenhamos, não é seguramente castigo dissuasor de novas distracções”. Com esta observação final, Mário de Carvalho promete reincidir numa estratégia literária que se lhe tem mostrado profícua.

\footnotetext{
${ }^{27} \mathrm{O}$ mesmo anacronismo da imagem foi de resto responsável por incompreensão equivalente da parte de um outro interveniente nos acontecimentos, a multidão neutra dos automobilistas. Confrontados eles também com a estranha presença do invasor, arriscaram diferentes interpretações (p. 30): "Que devia ser algum reclame, diziam uns; que era mas era para um filme, diziam outros". Outras confusões devidas ao mesmo motivo se irão acumulando, quando o combate já vai aceso; "interpretou mal" (p. 31), "pensou que era" (p. 32), são expressões multiplicadoras da incompatibilidade cronológica geral.
} 


\section{Conclusão}

Como em muitos dos seus textos, Mário de Carvalho recorre, em A inaudita guerra, a um bem sucedido processo de intertextualidade. E fá-lo, como é sua tendência, a partir de uma sugestão clara, assinalada com o nome de Homero, a que irá seguir-se um desafio ao leitor atento e informado. Porque, sob uma superfície de fantástico e anacrónico nos acontecimentos que sustentam a narrativa, está igualmente presente uma estranha confluência de géneros - o épico e o do conto breve -, cada um deles com os seus traços bem marcados. Fica sujeita à perspicácia do leitor a capacidade de encontrar, sob a ironia patente, as marcas do velho Homero, naquele que constitui o timbre central dos textos que lhe são atribuídos, sobretudo a Ilíada. Acontecimentos, figuras, estratégia descritiva são aproximáveis, de modo a que Lisboa se configure como uma nova Troia do séc. XX. Com mestria, Mário de Carvalho explora o que Aguiar e Silva (1982, p. 593) estabelece como a natureza elementar de qualquer texto literário: "um intercâmbio discursivo, uma tessitura polifónica na qual confluem, se entrecruzam, se metamorfoseiam, se corroboram ou se contestam outros textos, outras vozes e outras consciências".

\section{REFERÊNCIAS}

AGUIAR E SILVA, Vítor Manuel. Teoria da Literatura. 4. ed. Coimbra: Almedina, 1982.

COUTO, Rosa Maria. Subsídios para uma leitura orientada do conto $A$ inandita guerra da Avenida Gago Coutinho de Mário de Carvalho. Máthesis, v. 12, p. 313-25, 2003.

HALL, Edith. Aeschylus. Persians. Warminster: Aris and Philips, 1996.

LOURENÇO, Frederico. Homero. Ilíada. Lisboa: Cotovia, 2005.

PEREIRA, Anabela Soares; FLORES, Maria José. À descoberta da Língua Portuguesa $8^{\circ}$ ano. Porto: Edições Asa, 1999.

REIS, Carlos; LOPES, Ana Cristina. Dicionário de narratologia. Coimbra: Almedina, 2007.

SILVA, Maria de Fátima; BARBOSA, Tereza Virgínia. Ensaios sobre Mário de Carvalho. Coimbra: IUC, 2012.

SILVESTRE, Osvaldo. Revolução e Contra-Revolução ou um passo atrás e dois à frente. Colóquio/Letras, v. 147/148, p. 209-29, 1998.

VIEIRA, Maria Cecília. A História n' 'A inaudita guerra” de Mário de Carvalho. Lisboa: Universidade Aberta, 2009.

WEST, Martin. The making of the Iliad. Oxford: Oxford University Press, 2011. 